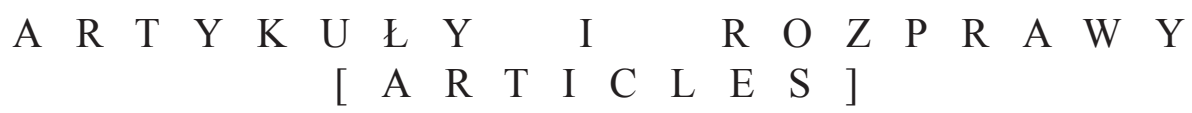

PETER JORDAN

https://doi.org/10.17651/ONOMAST.65.1.1

peter.jordan@oeaw.ac.at

Onomastica LXV, 2021

ORCID: 0000-0002-5656-0045

Institute of Urban and Regional Research, Austrian Academy of Sciences

Vienna, Austria

Faculty of Humanities, University of the Free State

Bloemfontein, South Africa

\title{
THE CRUCIAL AND CONTESTED CONCEPT OF THE ENDONYM/EXONYM DIVIDE
}

Keywords: exonym, toponymy, terminology, UNGEGN, cultural geography

\section{INTRODUCTION}

The recent session of the United Nations Group of Experts on Geographical Names (UNGEGN), held in a virtual format due to the Covid-19 pandemic between 3-7 May 2021 (UNGEGN, 2021a), revealed once again and perhaps even more drastically than ever how contested the concept of the endonym/ exonym divide is and how emphatically pros and cons related to exonyms are formulated. No other theme of the session prompted such vivid discussion.

It also revealed, however, that at least official, 'politically correct' attitudes towards exonyms conforming to state policies as they are usually expressed in these sessions have shifted from the attempts to reduce exonyms to a visible parity between exonym skeptics and exonym defenders. While the United Nations passed several resolutions in the 1970s and 1980s recommending the reduction and cautious use of exonyms, ${ }^{1}$ no such resolutions appeared later. On the contrary: the resolutions of the 2000s, appreciating traditional, inherited place names as parts of the cultural heritage, did not explicitly exclude exonyms, thus implicitly including them. ${ }^{2}$

The explanation for this remarkable shift can be found in a fundamental change of the political environment. Until the late 1980s, the global political situation was \footnotetext{
Res. V/13-1987 (UNGEGN, 2021b)

2 See Res. VIII/9-2002, IX/4-2007 and X/3-2012 (UNGEGN, 2021b)

1 See especially Res. II/29-1972, Res. II/35-1972, Res. III/18-1977, Res. IV/20-1982, 
marked by the Communist bloc with an internationalist ideology, demonizing exonyms as expressions of nationalism. Communist countries cooperated at that time within the framework of UNGEGN — remarkably enough — with anglophone countries, who regarded English exonyms not as exonyms in the narrower sense, but as international names that were anyway unavoidable and not in danger of being reduced. The third pillar of exonym sceptics comprised German-speaking countries with their language (including exonyms) stigmatized by the events of World War II and the atrocities of the Nazi regime. ${ }^{3}$

In the meantime, however, the Communist bloc disappeared. The hesitation of German-speakers to use their own exonyms is not as strong as before, due to the time which has elapsed since the end of World War II and with the new standing enjoyed by Germany and the German language in Europe (see Jordan, 2013). It is also a fact that the use of exonyms - despite UN resolutions demanding their reduction - underwent a strong revival after the fall of Communism in former Communist countries and has not at all been reduced elsewhere, probably because exonyms are simply needed and functional.

The remaining exonym sceptics in the ranks of UNGEGN experts, who are mainly recruited from Western Europe and North America, argue that modifying earlier UN resolutions or even declaring them obsolete would mean questioning the authority of $\mathrm{UN}$ resolutions and the $\mathrm{UN}$ in general.

This shows that the endonym/exonym divide has a remarkably political dimension and is obviously a crucial concept. Paul Woodman, a long-term British delegate to UNGEGN sessions and United Nations Conferences on the Standardization of Geographical Names (UNCSGN) as well as founding and senior member of the UNGEGN Working on Exonyms, has called it "the great toponymic divide" (Woodman, 2012). This article will try to substantiate this statement with arguments and provide an overview of different approaches to this divide.

\section{THE ENDONYM/EXONYM DIVIDE AS A CRUCIAL CONCEPT}

Place names can be regarded from various perspectives: what language they belong to, what etymology they have, what they mean, whether they are official or not, whether they are standardized or not, whether they have a commemorative

${ }^{3}$ The author of this paper did not participate in UNGEGN sessions before 1986 but was informed about earlier sessions and UN conferences on the standardization of geographical names (UNCSGN) in detail by his teacher in toponomastics and head of his department Josef Breu (1914-1998), Austrian delegate to UNGEGN sessions and UNCSGN from the very beginning, from 1977 to 1981 also UNGEGN chair. Breu was a defender of the use of exonyms and reported the enormous pressure exerted by Communist as well as anglophone countries in favor of exonym reduction in this period, to the extent that all what he could do was to defuse the wording of resolutions to some extent. 
function or are descriptive, what they mean for the space-related identity of people, etc. The aspect that leads to the distinction between endonym and exonym is the spatial relationship between the human community using the name and the geographical feature designated by that name.

\subsection{Endonyms mark a community's territory}

The aspect of the spatial relationship between the human community using the name and the geographical feature designated by that name is a sociological and geographical (spatial) one. It is but one of the many aspects of geographical names, yet a crucial one because it corresponds to two basic human attitudes, namely: (1) distinguishing between 'mine' and 'yours', 'ours' and 'theirs'; (2) territoriality, the desire to own a place expressed at all levels of human activity and community-building: the wish to own a flat or a house; even within a family apartment to have one's own room or at least one's own desk, where one can store one's personal belongings; at work, where we like to have our own office or at least our own desk; up to the level of countries that want to enforce their law and exercise their power in a well-defined territory.

It is the local community, the human group inhabiting a place or residing nearest to an uninhabited feature, that has an endonym. Marking a feature by an endonym means claiming possession of it or at least responsibility for it, indicating that others do not have the same right on this feature or not the same responsibility for it. This corresponds to the general meaning of naming as an expression of appropriation or assuming responsibility that is expressed in Genesis that says: "So Adam gave names to all cattle, to the birds of the air, and to every beast of the field". (Genesis 2:20).

If it does not use the endonyms of the other community, the above-mentioned community has exonyms for places and features in the area outside its own territory, to which it entertains frequent and close relations. Compared to the innumerable number of endonyms attributed to every geographical feature recognized as individual, exonyms are an exception and are used only for features of special importance for a receiver community. They are usually created by adapting the endonym to the receiver language orthographically or morphologically or by translating it partly, i.e., only the generic component, or completely to facilitate pronunciation, spelling and memorizing. In many cases exonyms are former endonyms of the receiver language that shifted from endonym to exonym status due to population exchange or older endonyms of the donor language, like the English exonym Prague and the German exonym Prag for the Czech endonym Praha, derived from the earlier Czech endonym Praga. It also sometimes transpires that exonyms are transferred by a mediator language — like many exonyms 
of Scandinavian languages for Italian cities have been mediated by German as the language of traders. It happens rather seldom that an exonym has no linguistic relation with the endonym. Hungarian Bécs and Croatian and Serbian Beč for Vienna [Wien] as well as Bulgarian, Serbian and Croatian Carigrad, together with outdated variants of this name in other Slavic languages for Istanbul [İstanbul], may serve as examples.

In contrast with endonyms, exonyms do not mark a community's territory, features in its possession or at least responsibility, but indicate (with some distortions caused by the acquaintance of receiver-language speakers with prestigious trade languages and linguistic relations between donor and receiver language) a community's pattern of historical and current cultural, economic, and political external relations (see Jordan, 2009, 2020). It can, however, not be denied that sometimes the use of exonyms is understood as a territorial claim or at least political nostalgia by receiver as well as donor-language speakers. This makes them politically sensitive and is certainly a still valid reason for UNGEGN's exonym skepticism addressed in the introduction. The danger of understanding them in this way is highest with exonyms that had earlier been endonyms and have lost this status due to population exchange. It is thus true that exonym use requires cultural and political sensitivity (see AKO, 2012; Jordan, 2000a, b).

\subsection{Endonyms support emotional relations to a place}

Besides marking one's own place and one's own territory, endonyms also have the important function of supporting emotional ties between humans and a place, although this is not the exclusive role of endonyms. Naming confirms the relationship a human being or a human community has entered with a section of geographical space, which for this very reason turns from space to place as Yi-Fu Tuan puts it (Tuan, 1974, 1977, 1991) or Bill Watt summed up in a short sentence: "Naming turns space into place" (Watt, 2009, p. 21).

Once the name, the endonym, has been established, it supports emotional ties between humans and their place. Reading, hearing or memorizing the name lets a plethora of associations arise - not only of the place's visual appearance, also memories of sounds and smells, of people and events. This emotional relationship supported by endonyms comprises not only the inhabited place, one's home in the narrower sense, but also one's daily perception of space, i.e., the landscape surrounding it, the mountains, lake, or sea forming its horizon. Everybody knows a set of place names that immediately evokes feelings of home.

Feelings of a close human-spatial relationship in the sense of place can also extend to the coastal waters of a sea, which for outsiders seem to be something closer to a wasteland, but to which coastal dwellers tend to be closely and emotionally 
related, because it is not only what they see day by day, but also an economic resource, a transportation and recreational area for them (see Jordan, 2019a, b).

It is, however, also true that exonyms can assume this function. Many of us not only have one place that evokes the feeling of coming home when we return there, but a second, a third and perhaps even more. This can lead us to emotionally relate to places far from our own community, supported by their exonyms. This emotional link may also relate us to names of places in which we have never been, but of which we are dreaming, and of which we have emotional images created by the media, the arts or tourism branding.

\subsection{Shared places and multiple identities}

Of course, a place can also be shared by communities — by a local majority and a local minority or several minorities. In this case, every local community may have its own endonym for this place and a place may have a couple of endonyms.

When human communities are understood not as coherence groups, but as identity groups in the sociological sense (see Weichhart et al., 2006) — in the sense of groups of people sharing a common identity - a multilayered hierarchy of communities exists, and one and the same person may very well identify himself/herself as belonging to several of these layers, have multiple space-related identities: member of a family, of a village community, a municipality, a regional administrative unit, a historical-cultural landscape, a nation, a language community or even the community of global citizens. Most of these levels are well-organized, active in naming and place-name standardization and apply their endonyms to geographical features within their area and range of responsibility. As with language in general, endonym and exonym use binds a community together and supports its identity.

\subsection{A divide escaping the criteria of language and officiality}

Different local communities can speak the same language but nevertheless apply different names to the same geographical feature. Thus, a lake can be named differently from opposite banks as is the case with Wolfgangsee or Abersee in Austria, although the same language (German) and even the same language variety is spoken around it. The Romanian river Mureş is called Mieresch by the German-speaking Saxons in Transylvania [Ardeal], but Marosch by the Danubian Swabians also speaking German. The endonym/exonym divide does thus not coincide with language boundaries.

This is also true with regard to the naming of places in non-local languages by a local community: An Italian restaurant named by its owners Mari e monti 
and known by this name in the local non-Italian speaking community is given an endonym, although the language of this name is otherwise not locally used. If the language of the name counted, the numerous English names for businesses, tourism and catering facilities as well as shopping centers and airports in many non-English speaking countries would be exonyms, although they have been chosen and are used and accepted by the local community.

\subsection{A divide covering all place names and transferable to other name categories}

In a certain place, a name can only belong to one of the two categories: either endonym or exonym. If it is used for a feature by the local community, the community inhabiting this place or nearest to it, it is an endonym (= a name from within the local community). If it is a name used by this same community for a feature outside their area or by another community for a feature in the area of the former community, differing from the endonym, it is an exonym. Thus, the Polish name Kraków is an endonym because the city is so called by the local community. If the same name is also used by outsiders, then they use the endonym. The English name Cracow or the German name Krakau, on the other hand, are exonyms because no autochthonous local community uses them.

While for geographical features that are located exclusively in the area of a community and not surpassing its boundaries, endonym and exonym status of a name are mutually exclusive, in the case of geographical features that cross community boundaries or that are shared by several local communities - such as longer rivers or mountain ranges - the situation is different. Then, the same name can be an endonym in one section/part of the feature and assume exonym status in another section/part of it, while it always designates the whole feature. The name Donau for the river, for example, is an endonym in its German and Austrian sections, while it assumes the status of an exonym east of Austria, where the name used by the local community, the endonym, is Dunaj in Slovakia, Duna in Hungary and the Vojvodina [Vojvodina, Vajdaság, Voivodina], Dunav in Croatia, Serbia and Bulgaria, Dunărea in Romania as well as Moldova and Dunaj again in Ukraine. All names, however, refer to the entire river. The English name Danube is an exonym everywhere, because no autochthonous English-speaking community resides along the river.

The status categories endonym and exonym comprise all place names. Each name can be attributed to one of these categories or corresponds to both (in the case of transboundary features differing by sections or parts of a feature). Endonym and exonym are therefore all-inclusive categories including all possible cases. They can even be applied to names of large, compact and completely 
uninhabited geographical features like oceans or Antarctica, for which all names would be exonyms, i.e., names from the outside and not used by an autochthonous local community. ${ }^{4}$

Endonym and exonym are in that respect also a basic onomastic pair of terms that is not only applicable to place names. It can in principle be transferred to names of all types of features to which an inside and an outside view applies, such as the names of

- persons: the self-designation (the name from within) would be the endonym, the (not always flattering) nickname (the name used by others) - the exonym.

- ethnic groups, nations: dignified self-descriptions (endonyms), which often mean simply 'people' or 'humans', are often contrasted with ironic or pejorative external names (exonyms) (see e.g. Manu, 2021)

- institutions, organizations: the endonym police is frequently contrasted with various ironic and derogatory exonyms.

\section{DIVERGENT APPROACHES AND CONCEPTS}

The distinction between endonyms and exonyms is, however, not as clear-cut as these explanations may suggest, and views on this pair of terms vary significantly. Apart from the exceptional view represented by Philip Matthews (2014) that endonyms were names conforming to the rules of a certain language and exonyms were names not conforming to them (which would mean that Cracow and Krakau were English and German endonyms, respectively, and Kraków was an exonym in these languages), the main difference is that some scholars regard endonyms and exonyms as two extreme ends of a continuum with a gradual transition between them, whereas others understand the relation between endonyms and exonyms as a dichotomy with no intermediate stages.

\subsection{The continuum view}

The continuum view acknowledges all efforts of a receiver language to remain as close to the endonym and the endophone (in the sense of the word in its local pronunciation) as possible and would not classify orthographic deviations from the endonym by diacritics, exchange of individual letters or even the translation of the generic as full-fledged exonyms.

Indeed, in many cases, where there is a small difference between the spelling of an endonym and an exonym, consisting e.g. in the omission or the addition of

\footnotetext{
${ }^{4}$ However, as already mentioned, the coastal waters of a sea, in visible distance from the coast, may rather be regarded as parts of the coastal dwellers ' territory', to which these dwellers are related in many ways, also emotionally, and their name has therefore endonym status.
} 
diacritics, the exchange of a letter or the addition of a vowel or a grammatical ending, this is done with the intention to reflect the original pronunciation, the endophone, as well as possible. It was not intended to create an exonym. On the contrary: if the endonym had not been adapted to the orthography of the receiver language, this would have resulted in a pronunciation much more different from the endophone with the receiver community. A case in point is the Croatian spelling of the Romanian endonym Câmpulung as Kimpolung. Had the letter $C$ not been replaced by $K$ and $\hat{a}$ by $i$, Croatian speakers would pronounce the name differently from the endophone. Thus, deviating from the endonym in writing can result in achieving an endophone in pronunciation and vice versa.

A next step in deviation from the endonym in writing is the addition of a vowel or a grammatical ending typical of Italian, in which language $a$ is added to the German endonym Bern (resulting in Berna) to conform to Italian phonotactics, or by Latvian, in which Gente is an equivalent of the Dutch Gent. Another step further is script conversion, when the endonym is written in a different script, either by phonetic transcription or transliteration. A next step already transcending a deviation in writing is the translation of a generic.

Linguists like Jarno Raukko (2007), Peeter Päll (2000, 2011, 2014, 2015; Päll \& Matthews, 2007), Ojārs Bušs (2012, 2014, 2015, 2016) and Philip Matthews (2014; Päll \& Matthews, 2007) postulate that it is necessary to discern between linguistically avoidable and unavoidable transformations of the endonym, when it is used by speakers of another language. Accordingly, they propose to regard names resulting from linguistically unavoidable transformations, not as exonyms, at least not in the full sense. For instance, Peeter Päll proposed a new terminology, discerning between endonyms (е.g. Москва), endonymoids obtained by a conversion of scripts (e.g. Moskva) or adapting name endings (e.g. Stokholma or Stockholma), exonyms (e.g. Moscow), and exonymoids obtained by a translation of generic terms, omission or alteration of diacritical marks, declension or derivation (Päll, 2011, pp. 92-93).

Päll and other linguists would thus regard endonyms and exonyms not as strictly opposed, but as the two ends of a gradual transition, in which 'exonymity' gains at the expense of 'endonymity'.

\subsection{The dichotomy view}

The dichotomy view corresponding to a cultural-geographical perspective, however, only regards names completely conforming to local use and accepted by locals as endonyms. It departs from the assumption that the local community will perceive even the slightest deviation from their name in spelling as alienating it, as creating a name version used by others, not by themselves, thus as an exonym. 
Regarding it from the receiver language perspective, the slightest adaptation of a name to the receiver language would already show the attempt of a receiver community to integrate the foreign feature designed by this name into their cultural sphere and to avoid its exclusion and alienation - as it is the most important function of exonyms according to Otto Back (2002). Already the use of Riga for Rìga or Istanbul for Istanbul would be regarded by the local community as alienated, not to speak of finding Вариава instead of Warszawa or Кракув instead of Kraków on the town signs of these cities.

It would also be difficult to argue why a minority name deviating from the name in the majority language only by a diacritic has to appear additionally on a town sign for identity reasons, when a name alienated by diacritics or even transcribed counts as an endonym.

It must also be emphasized in this context that an endonym does not only have to be used by the local community, but to be accepted by it as well. An official name is not eo ipso an endonym. It may happen that an occupation power or another dominant political force makes place names official that are not or hardly ever used by the local population. A case in point is the Nazi occupation of Poland in World War II, when e.g. the city of Łódź received the official name Litzmannstadt, although even the local German minority still existing at the time used Lodsch, i.e. the Polish name in German orthography. Another example is the Italian fascist naming policy in South Tyrol [Alto Adige/Südtirol] after World War I, when Italian names were imposed as official ones on places without any Italian-speakers. A third case is the situation in Sudan, where the Nubian minority has their own local names, but Arab names are the only official ones (Bell, 2012, 2014, 2015, 2018, 2019; Sabbār, 2011, 2012, 2014, 2015; Bell, Sabbār, 2011).

\subsection{Definitions}

The following definitions of endonym and exonym conform more or less to both approaches to the endonym/exonym divide, but mainly due to their rather general wording.

The first are the definitions developed by the UNGEGN Working Group on Exonyms in intensive discussions between 2007 and 2014 (see Jordan, Bergmann, Burgess \& Cheetham, 2011; Jordan \& Woodman, 2014; Jordan \& Woodman, 2015), but never elevated to the status of official UNGEGN Glossary definitions due to a politically motivated veto.

- Endonym: name accepted and used by the local community.

- Exonym: name not used by the local community and different from the endonym. 
Thus, the UNGEGN Glossary definitions of 2007 were not modified or replaced and run as follows (Kadmon, 2007, p. 2):

- Endonym: name of a geographical feature in an official or well-established language occurring in that area where the feature is situated. Examples: Vārānasī (not Benares); Aachen (not Aix-la-Chapelle); Krung Thep (not Bangkok); Al-Uqşur (not Luxor).

- Exonym: name used in a specific language for a geographical feature situated outside the area where that language is widely spoken, and differing in its form from the respective endonym(s) in the area where the geographical feature is situated. Examples: Warsaw is the English exonym for Warszawa (Polish); Mailand is German for Milano; Londres is French for London; Külüniyā is Arabic for Köln. The officially romanized endonym Moskva for Москва is not an exonym, nor is the Pinyin form Beijing, while Peking is an exonym. The United Nations recommends minimizing the use of exonyms in international usage. See also these definitions.

In contrast with the definitions mentioned above, the UN glossary definitions regard names in official languages eo ipso as endonyms and do not refer to communities, but to languages excluding an intra-language endonym/exonym divide. They also accept transliterated names as endonyms, which would be excluded by the definitions mentioned above. Not explicitly mentioned in these definitions but defined by UN Resolution III/19-1977 (UNGEGN, 2021b), names differing from the official name only by the omission, addition or alteration of diacritics or the article, by declension or derivation or created by the translation of a generic term are regarded as exonyms, which brings these definitions closer to the dichotomy than to the continuum approach.

The International Council of Onomastic Sciences (ICOS) in its List of Key Onomastic Terms presents the following definitions (ICOS, 2021, p. 2):

- Endonym: proper name of a geographical feature in an official or well-established language occurring in that area where the feature is situated - e.g. Venezia in Italian (not Venice), Praha in Czech (not Prague).

- Exonym: name used in a specific language for a geographical feature situated outside the area where that language is widely spoken and differing in its form from the name used in the area where the geographical feature is situated e.g. French Londres for London, German Warschau for Warszawa, Bangkok for Krung Thep, Spanish Ginebra for Genève.

These definitions repeat the definitions of the UNGEGN Glossary 2007 with slight variations and thus refer, like UNGEGN ones, to language as the criterion constitutive for the endonym/exonym divide. An intra-language divide is not envisaged, and official names are eo ipso endonyms. In contrast with the UNGEGN definitions, they do not explicitly classify transliterated names as endonyms. 
Characteristically enough, none of the definitions makes it clear whether the divide is based on the written or the spoken name. Confining the divide to the written form would mean the exclusion of the spoken divide arising in East Asian writing systems like kanji, while the written form is the same (Choo, 2015; Tanabe, 2015). Explicitly including the spoken name, while in practice the endonym/exonym divide, apart from the Sinosphere, refers to the written form, would on the other hand mean a huge increase in the number of exonyms, since hardly any endonym is pronounced correctly outside the endonym community. The task of combining the two practices in the same definitions remains still to be resolved.

\section{CONCLUSION}

Coinciding with basic human attitudes, such as discerning between 'mine' and 'yours', 'ours' and 'theirs', as well as human territoriality, the endonym/exonym divide is certainly a crucial scientific concept. Its importance is emphasized by the fact that mainly endonyms support emotional relations to place, although in the case of exonyms, this cannot be excluded either. Its role as a crucial concept is further underlined by its transferability from place names to other name categories.

Two divergent approaches, however, make it difficult to arrive at definitions of endonym and exonym that are all-inclusive and precise at the same time. While the linguistic approach regards the divide rather as a continuum with several transitional stages closer to the endonym or the exonym, the cultural-geographical approach accepts the spatial relation between name user and the feature designated by the name as the exclusive criterion.

\section{REFERENCES}

Arbeitsgemeinschaft für Kartographische Ortsnamenkunde (AKO). (2012). Empfehlungen zur Schreibung geographischer Namen in österreichischen Bildungsmedien. Wien: Verlag der Österreichischen Akademie der Wissenschaften.

Back, O. (2002). Übersetzbare Eigennamen. Eine synchrone Untersuchung von interlingualer Allonymie und Exonymie. Wien: Praesens.

Bel1, H. (2012). Nubian perceptions of exonyms and endonyms. In P. Woodman (Ed.), The Great Toponymic Divide. Reflections on the Definition and Usage of Endonyms and Exonyms (pp. 97-104). Warszawa: Główny Urząd Geodezji i Kartografii.

Be11, H. (2014). Toponymic teleology: Endonyms in an endangered language. In P. Jordan, \& P. Woodman (Eds.), The Quest for Definitions. Proceedings of the $14^{\text {th }}$ UNGEGN Working Group on Exonyms Meeting, Corfu, 23-25 May 2013 (= Name \& Place, 3) (pp. 175-184). Hamburg: Verlag Dr. Kovač. 
Be11, H. (2015). A multilingual environment: Its relevance for defining 'endonym' and 'exonym'. In P. Jordan, \& P. Woodman (Eds.), The Confirmation of the Definitions. Proceedings of the $16^{\text {th }}$ UNGEGN Working Group on Exonyms Meeting, Hermagor, 5-7 June 2014 (=Name \& Place, 4) (pp. 117-122). Hamburg: Verlag Dr. Kovač.

Be11, H. (2018). The dynamics of exonyms and an accusation of 'cultural suicide'. In P. Jordan, I. Švehlová, \& P. Woodman (Eds.), A Survey of Exonym Use. Proceedings of the $19^{\text {th }} U N G E G N$ Working Group on Exonyms Meeting, Prague [Praha], 6-8 April 2017 (= Name \& Place, 7) (pp. 185-191). Hamburg, Verlag Dr. Kovač.

Bell, H. (2019). Exonyms perceived by a scholar who spoke an unofficial language. In A. Dollimore, \& K. Watanabe (Eds.), The Classification of Exonyms. Proceedings of the $21^{\text {st }}$ UNGEGN Working Group on Exonyms Meeting, Riga [Rìga], 24-26 September 2018 (= Name \& Place, 8) (pp. 97-110). Hamburg, Verlag Dr. Kovač.

Bell, H., \& Sabbār, H. (2011). Nubian geographical names and language revitalization on both sides of an international border. In P. Jordan, H. Bergmann, C. Burgess, \& C. Cheetham (Eds.), Trends in Exonym Use. Proceedings of the $10^{\text {th }}$ UNGEGN Working Group on Exonyms Meeting, Tainach, 28-30 April 2010 (= Name \& Place, 1) (pp. 295-311). Hamburg: Verlag Dr. Kovač.

Bušs, O. (2012). On some possibilities for a more exact definition of exonyms. In P. Woodman (Ed.), The Great Toponymic Divide. Reflections on the Definition and Usage of Endonyms and Exonyms (pp. 67-73). Warszawa: Główny Urząd Geodezji i Kartografii.

Bušs, O. (2014). Two kinds of endonyms/exonyms - two kinds of interpretation problems. In P. Jordan, \& P. Woodman (Eds.), The Quest for Definitions. Proceedings of the $14^{\text {th }} U N G E G N$ Working Group on Exonyms Meeting, Corfu, 23-25 May 2013 (=Name \& Place, 3) (pp. 49-54). Hamburg: Verlag Dr. Kovač.

Bušs, O. (2015). Don’t we have at least some exonyms for foreign geographical features? In P. Jordan, P. Woodman (Eds.), Confirmation of the Definitions. Proceedings of the $16^{\text {th }} U N G E G N$ Working Group on Exonyms Meeting, Hermagor, 5-7 June 2014 (= Name \& Place, 4) (pp. 25-30). Hamburg: Verlag Dr. Kovač.

Bušs, O. (2016). Should we use new terms? Are exonymoid and endonymoid appropriate terms? In P. Jordan, \& P. Woodman (Eds.), Criteria for the Use of Exonyms. Proceedings of the $17^{\text {th }}$ UNGEGN Working Group on Exonyms Meeting, Zagreb, 14-16 May 2015 (= Name \& Place, 6) (pp. 93-98). Hamburg: Verlag Dr. Kovač.

Choo, S. (2015). The endonym/exonym divide in the context of Korean geographical names. In P. Jordan, \& P. Woodman (Eds.), Confirmation of the Definitions. Proceedings of the $16^{\text {th }}$ UNGEGN Working Group on Exonyms Meeting, Hermagor, 5-7 June 2014 (= Name \& Place, 4) (pp. 139-141). Hamburg: Verlag Dr. Kovač.

International Council of Onomastic Sciences (ICOS) (2021). https://icosweb.net/publications/onomastic-terminology/

Jordan, P. (2000a). The importance of using exonyms — pleading for a moderate and politically sensitive use. In J. Sievers (Ed.), Second International Symposium on Geographical Names "GeoNames 2000" Frankfurt am Main, 28-30 March 2000 (= Mitteilungen des Bundesamtes für Kartographie und Geodäsie, 19) (pp. 87-92). Frankfurt am Main: Bundesamt für Kartographie und Geodäsie.

Jordan, P. (2000b). Vom Wert der Exonyme. Plädoyer für einen maßvollen und politisch sensiblen Gebrauch. In M. Lechthaler, \& G. Gartner (Eds.), Per aspera ad astra. Festschrift für Fritz Kelnhofer zum 60. Geburtstag (pp. 52-71). Wien: Technische Universität Wien. Institut für Kartographie und Reproduktionstechnik.

Jordan, P. (2009). Exonyms as indicators of trans-national spatial relations. Review of Historical Geography and Toponomastics, 4(7-8), 7-16. 
Jordan, P. (2013). Trends in exonym use of European school atlases. In P. Jordan, \& F. Ormeling (Eds.), Toponyms in Cartography. Proceedings of the Toponymic Sessions at the $25^{\text {th }}$ International Cartographic Conference, Paris, 3-8 July 2011 (= Name \& Place, 2) (pp. 31-46). Hamburg: Verlag Dr. Kovač.

Jordan, P. (2019a). Role of place names in relating people and space. In S.D. Brunn, \& R. Kehrein (Eds.), Handbook of the Changing World Language Map (pp. 2037-2051). Cham: Springer Nature Switzerland AG.

Jordan, P. (2019b). The endonym/exonym divide from a cultural-geographical perspective. Language and Society, 10, 5-21.

Jordan, P. (2020). Croatian external relations as reflected by the use of exonyms. Studia lexicographica, 14, 63-83.

Jordan, P., Bergmann, H., Burgess, C., \& Cheetham, C. (Eds.). (2011). Trends in Exonym Use. Proceedings of the $10^{\text {th }}$ UNGEGN Working Group on Exonyms Meeting, Tainach, 28-30 April 2010 (= Name \& Place, 1). Hamburg: Verlag Dr. Kovač.

Jordan, P., \& Woodman, P. (Eds.). (2014). The Quest for Definitions. Proceedings of the $14^{\text {th }}$ UNGEGN Working Group on Exonyms Meeting, Corfu, 23-25 May 2013 (= Name \& Place, 3). Hamburg: Verlag Dr. Kovač.

Jordan, P., \& Woodman, P. (Eds.). (2015). The Confirmation of the Definitions. Proceedings of the $16^{\text {th }}$ UNGEGN Working Group on Exonyms Meeting, Hermagor, 5-7 June 2014 (= Name \& Place, 4). Hamburg: Verlag Dr. Kovač.

Kadmon, N. (Ed.). (2007). Glossary of Terms for the Standardization of Geographical Names: Addendum. UN Document ST/ESA/STAT/SER.M/85/Add.1, 07-60262, 16 November 2007. New York: United Nations. https:/unstats.un.org/unsd/ungegn/pubs/documents/Glossary_of_ terms_rev.pdf

Manu, M.M. (2021). Ethnonyms used for and by Romanian migrant groups in Transylvania and their reflections in toponymy. In A. Dollimore, \& P. Jordan (Eds.), Place Names and Migration. Proceedings of the Symposium in Vienna, 6-8 November 2019 (= Name \& Place, 9) (pp. 217-227). Hamburg: Verlag Dr. Kovač.

Matthews, P. (2014). Endonyms and exonyms: Proposed definitions. In P. Jordan, \& P. Woodman (Eds.), The Quest for Definitions. Proceedings of the $14^{\text {th }} U N G E G N$ Working Group on Exonyms Meeting, Corfu, 23-25 May 2013 (= Name \& Place, 3) (pp. 83-143). Hamburg: Verlag Dr. Kovač.

Päll, P. (2000). Do conventional romanization systems create exonyms? In J. Sievers (Ed.), Second International Symposium on Geographical Names “GeoNames 2000” Frankfurt am Main, 28-30 March 2000 (= Mitteilungen des Bundesamtes für Kartographie und Geodäsie, 19) (pp. 137-140). Frankfurt am Main: Bundesamt für Kartographie und Geodäsie.

Päl1, P. (2011). Conversion of scripts, and exonyms. In P. Jordan, H. Bergmann, C. Burgess, \& C. Cheetham (Eds.), Trends in Exonym Use. Proceedings of the $10^{\text {th }}$ UNGEGN Working Group on Exonyms Meeting, Tainach, 28-30 April 2010 (= Name \& Place, 1) (pp. 89-93). Hamburg: Verlag Dr. Kovač.

Pä11, P. (2014). Exonyms: The special case of countries with non-Roman scripts. In P. Jordan, \& P. Woodman (Eds.), The Quest for Definitions. Proceedings of the $14^{\text {th }}$ UNGEGN Working Group on Exonyms Meeting, Corfu, 23-25 May 2013 (= Name \& Place, 3) (pp. 147-152). Hamburg: Verlag Dr. Kovač.

Päl1, P. (2015). Spelling differences and exonyms. In P. Jordan, \& P. Woodman (Eds.), Confirmation of the Definitions. Proceedings of the $16^{\text {th }}$ UNGEGN Working Group on Exonyms Meeting, Hermagor, 5-7 June 2014 (= Name \& Place, 4) (pp. 111-116). Hamburg: Verlag Dr. Kovač.

Pä1l, P., \& Matthews, P.W. (2007). Some linguistic aspects of defining exonyms. In P. Jordan, M. Orožen Adamič, \& P. Woodman (Eds.), Exonyms and the International Standardisation 
of Geographical Names. Approaches towards the Resolution of an Apparent Contradiction (= Wiener Osteuropa Studien, 24) (pp. 69-79). Wien-Berlin: LIT Verlag.

Raukko, J. (2007). A linguistic classification of exonyms. In P. Jordan, M. Orožen Adamič, $\&$ P. Woodman (Eds.), Exonyms and the International Standardisation of Geographical Names. Approaches towards the Resolution of an Apparent Contradiction (= Wiener Osteuropa Studien, 24) (pp. 19-57). Wien-Berlin: LIT Verlag.

Sabbār, H. (2011). The toponymy of Ishkéed and the revitalization of an endangered Nubian language. In P. Jordan, H. Bergmann, C. Burgess, \& C. Cheetham (Eds.), Trends in Exonym Use. Proceedings of the $10^{\text {th }}$ UNGEGN Working Group on Exonyms Meeting, Tainach, 28-30 April 2010 (= Name \& Place, 1) (pp. 313-317). Hamburg: Verlag Dr. Kovač.

Sabbār, H. (2012). Numbers as geographical names in Nubia: Endonyms or exonyms? In P. Woodman (Ed.), The Great Toponymic Divide. Reflections on the definition and usage of endonyms and exonyms (pp. 105-110). Warszawa: Główny Urząd Geodezji i Kartografii.

S abbār, H. (2014). Language: An essential element of the endonym. In P. Jordan, \& P. Woodman (Eds.), The Quest for Definitions. Proceedings of the $14^{\text {th }}$ UNGEGN Working Group on Exonyms Meeting, Corfu, 23-25 May 2013 (= Name \& Place, 3) (pp. 185-190). Hamburg: Verlag Dr. Kovač.

Sabbār, H. (2015). Disenfrenchising indigenous languages. The need to define 'endonym' and 'exonym' with accuracy and fairness. In P. Jordan, \&P. Woodman (Eds.), The Confirmation of the Definitions. Proceedings of the $16^{\text {th }}$ UNGEGN Working Group on Exonyms Meeting, Hermagor, 5-7 June 2014 (= Name \& Place, 4) (pp. 123-126). Hamburg: Verlag Dr. Kovač.

Tanabe, H. (2015). Difficulties of the exonym/endonym dichotomy from the viewpoint of East Asian place names. In P. Jordan, \& P. Woodman (Eds.), Confirmation of the Definitions. Proceedings of the $16^{\text {th }}$ UNGEGN Working Group on Exonyms Meeting, Hermagor, 5-7 June 2014 (= Name \& Place, 4) (pp. 129-138). Hamburg: Verlag Dr. Kovač.

Tuan, Yi-Fu (1974). Topophilia. A Study of Environmental Perception, Attitudes, and Values. New Jersey: Prentice Hall.

Tuan, Yi-Fu (1977). Space and place: The Perspective of Experience. Minneapolis: University of Minnesota Press.

Tuan, Yi-Fu (1991). Language and the making of place: A narrative-descriptive approach. Annals of the Association of American Geographers, 81, 684-696.

United Nations Group of Experts on Geographical Names (UNGEGN) (2021a). https://unstats.un.org/ unsd/ungegn/sessions/2nd_session_2021/

United Nations Group of Experts on Geographical Names (UNGEGN) (2021b). https://unstats. un.org/unsd/ungegn/resolutions/

Watt, B. (2009). Cultural aspects of place names with special regard to names in indigenous, minority and regional languages. In P. Jordan, H. Bergmann, C. Cheetham, \& I. Hausner (Eds.), Geographical Names as a Part of the Cultural Heritage (= Wiener Schriften zur Geographie und Kartographie, 18) (pp. 21-24). Wien: Institut für Geographie und Regionalforschung der Universität Wien. Kartographie und Geoinformation.

Weichhart, P., Weiske, Ch., \& Werlen, B. (2006). Place Identity und Images: Das Beispiel Eisenhüttenstadt (= Abhandlungen zur Geographie und Regionalforschung, 9). Wien: Universität Wien. Institut für Geographie und Regionalforschung.

Woodman, P. (Ed.). (2012). The Great Toponymic Divide: Reflections on the definitions and usage of endonyms and exonyms. Warszawa: Główny Urząd Geodezji i Kartografii. 


\section{SUMMARY}

\section{THE CRUCIAL AND CONTESTED CONCEPT OF THE ENDONYM/EXONYM DIVIDE}

Paul Woodman has called it the "great toponymic divide", but the endonym/exonym distinction is not a concept confined solely to toponymy, it can be transferred to all name categories, where the name used by insiders may differ from the name used by outsiders, e.g., to ethnonyms, anthroponyms, names of institutions, where we frequently meet, for instance nicknames and derogative designations used by outsiders. But there is no doubt that this divide has its focus on toponymy, since it corresponds there to two basic human attitudes: (1) to the distinction between 'mine' and 'yours', 'ours' and 'theirs', and (2) to territoriality, the desire to own a place, which appears at all levels of the construction of human community - from the level of the family up to that of nations. Thus, it has always a political, social, and juridical meaning and is frequently a reason for dispute and conflict. However, even after long and intensive discussions, e.g., in the UNGEGN Working Group of Exonyms, to date we can still see rather divergent approaches to this divide. There is the linguistic approach regarding the endonym and the exonym rather as poles of a continuum, with various intermediary stages. Alternatively, there is the cultural-geographical approach that accepts no other criteria than the spatial relation between the name-using community and the geographical feature denoted by the name. The article elaborates on these items, mainly on the basis of the discussions and publications of the UNGEGN Working Group on Exonyms since 2002. 